\title{
The implication of AIRQUAL and brand credibility on passengers' satisfaction in airlines industry
}

\author{
Terrylina A Monoarfa ${ }^{a}$, Osly Usman ${ }^{a^{*}}$ and Tausyanah ${ }^{\mathrm{b}}$
}

${ }^{a}$ Faculty of Economics, Universitas Negeri Jakarta, Indonesia

${ }^{b}$ Faculty of Economics, Universitas Negeri Semarang, Indonesia

\section{H R O N I C L E}

\section{Article history:}

Received: May 30, 2020

Received in revised format:

May 302020

Accepted: June 19, 2020

Available online:

June 19, 2020

Keywords:

Service Quality

Brand Credibility

Passenger's Satisfaction

Behavioral Intention

\begin{abstract}
A B S T R A C T
This study aims to investigate the implications of service quality and brand credibility on passenger satisfaction and behavioral intentions in the air transportation industry in Indonesia, especially at Lion Air. This research is motivated by the high level of passenger complaints against Lion Air services in seven years, according to the Indonesian Consumers Foundation (YLKI). The most common complaints include frequent flight delays, less timely return of tickets, damage and lost luggage, even lower safety guarantees. This is considered not only as a manifestation of poor service quality, but also affects brand credibility in the long run. In addition, poor service quality and brand credibility show low passenger satisfaction and influence changes in their behavioral intentions in the future. Respondents in this study were Lion Air passengers at least once several times using Lion Air in the last two years. The study uses Structural Equation Modeling and Partial Least Square (SEM-PLS) to examine the hypotheses of the survey. Data analysis techniques are carried out through three stages, such as inner models, external models, and hypothesis testing. Then, this study states that there is a positive and significant impact of service quality and brand credibility on behavioral intentions with passenger satisfaction as a mediating variable.
\end{abstract}

\section{Introduction}

Air transportation is one of the vital facilities that must be a concern of all parties in its operations. In 2019, Indonesia recorded 237 airports, one of which was Soekarno Hatta Airport, which was ranked 18th as the busiest airport in the world with 66.9 million passengers per year (International Airport Review, 2019). Discussing about the air transportation industry, it is not enough about how to present good airport facilities, but also excellent flight services. In general, there are two types of commercial airline services (passengers), namely full-service airlines and low-cost airlines (LCC). Lion Air is one of the most dominant domestic airlines in Indonesia. However, several issues related to the low quality of service and the credibility of Lion Air are still often heard. The Indonesian Consumers Foundation (YLKI) has noted that Lion Air is one of the airlines with the highest level of consumer complaints even over the last seven years, mainly related to the slow refund of cancellation of ticket purchasing, flight delays, damage and loss of baggage, up to the low of safety standards (Fadhilah \& Puspita, 2018; Rush, 2015). In addition, according to worldairlineawards (2020) in the category of Low-Cost Airlines, in 2019 AirAsia was ranked first as the best LCC airline in the world in the air transportation industry. Referring to customer complaint data, Lion Air might be said to be not optimal in providing the best service to their customers. However, Topbrand (2019) states that Lion Air is considered to have a high level of brand popularity with a top brand index (TBI) of 19.2\%, below Garuda Indonesia Airlines, which is in first place with a TBI of $40.5 \%$. Another issue cited by Australian electronic media citing the frequent causes of flight schedule delays, poor quality of service personnel, and lack of safety measures for flights is the effect of Lion Lion's overcrowded flight schedules. In addition, excessive pilot workload is likely to cause Lion Air JT610 aircraft accidents around the Java Sea which caused 189 deaths in October 2018. As well as airworthiness due to technical reasons (Hodge \& 
Rayda, 2018). Credibility refers to the level of trust that is reflected in the willingness and ability of a brand to deliver on their promises to customers (Spry, Pappu, \& Cornwell, 2011). When airlines are able to provide high quality services, brand credibility grows positively. So, not only customer satisfaction is certain, but also the intention of customer behavior is indicated by the existence of repeated purchases. In addition, satisfaction is often reflected by the customer's desire to create word of mouth through their recommendations to others about experiences (Jiang, Li, Liu, \& Chang, 2017; Kos Koklic, Kukar-Kinney, and Vegelj, 2017; Leong Hew, Lee, \& Ooi, 2015; Rajaguru, 2016). As such, it should be considered to conduct further research on the implications of service quality and brand credibility on the behavioral intentions of Lion Air passengers.

\section{Theoretical background}

\subsection{Service quality}

Lewis and Booms explained that service quality is related to the company's ability to provide services to customers in accordance with customer expectations (Parasuraman \& Berry, 1998). Furthermore, Zeithaml, Berry, and Parasuraman (1996) stated that service quality can be defined as customers' impressions of service companies whose service quality is delivered in accordance with customer expectations. Through the SERVQUAL model, service quality can be measured through five dimensions, namely tangibles, reliability, responsiveness, assurance, and empathy. As tangibles, the physical evidence includes interior design, personnel appearance, and equipment completeness; reliability is the company's ability to organize services accurately; responsiveness is the company's willingness to provide assistance to customers quickly; assurance is the company's ability to provide quality assurance to consumers (related to services in certain knowledge, polite attitude, and the ability of personnel who are able to provide a sense of security to customers); while empathy is the readiness of companies and personnel to provide personalized services to customers (Cronin, J. \& Taylor, S., 1992). Furthermore, to measure service quality the SERVPERF model was developed which places more emphasis on service performance. Where service performance is measured by comparing expectations, perceptions, and actual service performance at a certain time (Ekiz, Hussain, and Bavik, 2015; Karatepe and Avci, 2002). Then in the air transportation industry, the quality of service measurement developed into the AIRQUAL model (Alotaibi \& John Mason, 2010; Ekiz et al., 2015; Nadiri et al., 2008). Where the dimensions of service quality are terminal tangibles, airline tangibles, personnel, empathy, and image. The AIRQUAL model is considered more appropriate for evaluating quality services in the air transportation industry. In this model, the physical quality of service (physical evidence) is measured according to the performance of flight services while on a flight as well as the quality of service when at the departure terminal. In addition, the quality of personnel and empathy is closely related to the desire to provide personal service to passengers is a measure used by this model. In addition, the dimensions of service quality are images that explain the impression felt by passengers when receiving service. The AIRQUAL model is considered more appropriate for evaluating quality services in the air transportation industry. In this model, the physical quality of service (physical evidence) is measured according to the performance of flight services while on a flight as well as the quality of service when at the departure terminal. In addition, the quality of personnel and empathy is closely related to the desire to provide personal service to passengers is a measure used by this model. In addition, the dimensions of service quality are images that explain the impression felt by passengers when receiving service.

\subsection{Brand credibility}

The concept of brand credibility is an extension of Brand Signaling Theory which explains that consumers can capture information about the company both directly and indirectly through the received signal (asymmetric information). The essence of brand signaling theory is about clarity and credibility. Where clarity can be defined as the absence of ambiguity in information, while credibility is how effective the signal of brand information is given (related to the accuracy and reliability of information). Credibility can be considered a key element in brand signals (Spry et al., 2011). Brand signaling theory is often used as a strategy to build a company's position. The company indirectly sends signals (asymmetric information) to consumers about the company's position. For example, when companies make price changes, consumers will receive a signal of what is happening in this company. Or when companies change their logos or taglines, there are messages and hopes consumers will catch about what changes will be brought about in the future about a brand. Even when consumers get information about negative customer testimonials or comments about a brand, often this will be used as a basis for consumers' assessment of the brand's credibility. The signals captured by consumers will vary greatly. Depending on the level of sensitivity of consumers in receiving signals and interpreting messages. However, this shows that brand credibility is very important to influence subsequent consumer decisions (Erdem \& Louviere, 2002; Erdem \& Swait, 2004; Erdem, Swait, and Valenzuela, 2006). Other opinions regarding brand credibility such as Connelly in Shafranskaya \& Potapov (2014) state that brand credibility is about the company's ability to realize what is promised to consumers. The dimensions used to measure brand credibility are expertise and trustworthiness. Where expertise explains how the company's ability to realize its commitment to consumers, related to the competence of a brand in the industry. While trustworthiness explains the company's ability to foster consumer trust and trust (Erdem \& Swait, 2004). Brand credibility is an important factor that influences consumer behavior intentions. In addition to service quality, brand credibility determines consumer purchasing decisions in the future. Consumers will manage the captured signal based on brand credibility, then validate the quality of service that was once felt as a consideration for the next decision (Jeng, 2016). 


\subsection{Customer satisfaction}

According to Armstrong, Kotler, Harker, and Brennan (2018) customer satisfaction is a feeling of pleasure or disappointment over the performance of a product / company by comparing expectations and previous feelings after consuming a product or service. Likewise, Oliver mentioned that customer satisfaction is a post-purchase evaluation of consumers (Farooq et al., 2018; Kim \& Lee, 2011). Furthermore, customer satisfaction will be reflected in the sustainability of consumers in consuming products or services and the ability of consumers to benefit the company (profitability) in the future. So that customer satisfaction is often translated as the beginning of customer loyalty, which is indicated by the existence of repeated purchases, and the willingness of customers to provide recommendations for products or services to others, or even create word of mouth communication.

\subsection{Behavioral intention}

The concept of behavioral intentions and measurability has been developed by Zeithaml et al. (1996), Where based on research Kim \& Lee (2011) the dimensions of the communication behavior intention include word-of-mouth, repeat purchase, price sensitivity, and behavior of complaints (complaining behavior).

\section{Research methodology}

This study used survey method with descriptive approach. The model used in this study is a model of causality (causal modeling) or relationship and influence, or also called path analysis (path analysis). To test the hypotheses proposed in this study the model fit analysis technique used is SEM (Structural Equation Modeling) which is operated using a 3.0 SMARTPLS program. In the PLS method, technique analysis was conducted on the three phases of analysis models outer, inner analysis models, hypothesis testing. Details of the questionnaire used for this survey are given in Table A1 in Appendix. Fig. 1 also shows the summary of the proposed model.

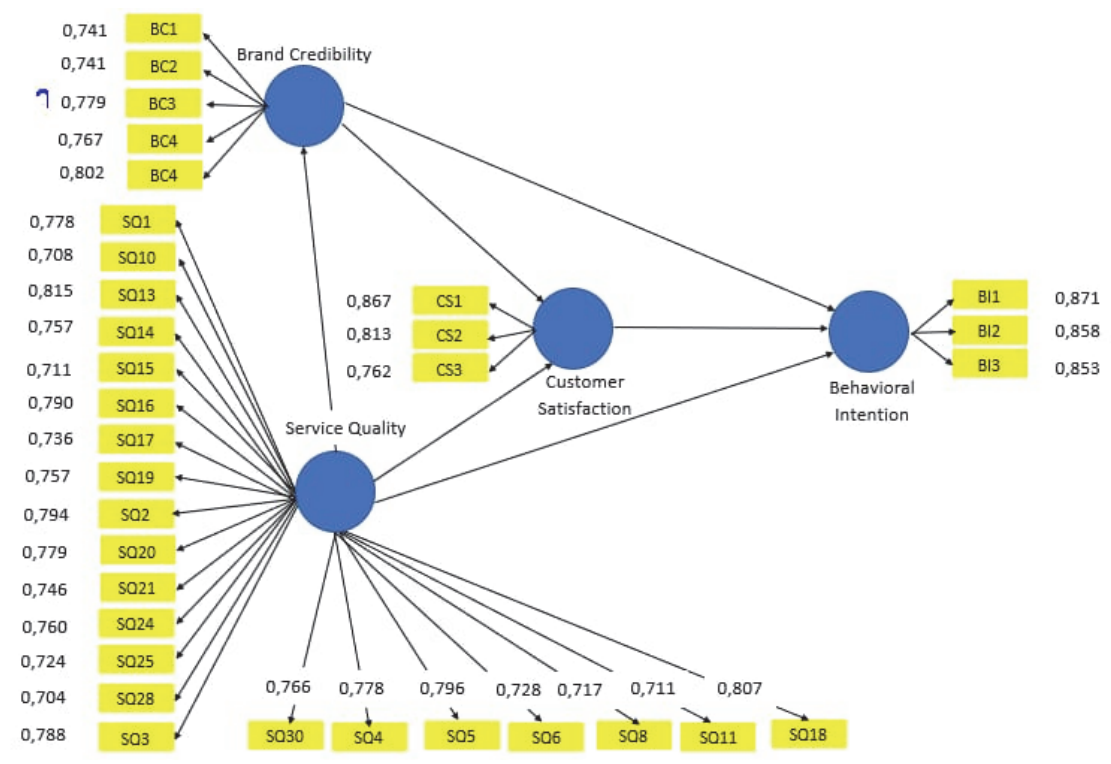

Fig. 1. The proposed study

\subsection{Outer Analysis Model}

Analysis of the model outer aims to determine how the relationship between the latent variables with each indicator. Cronbach's alpha value is used to determine the level indicator of each construct validity. If the Cronbach alpha value is more than 0.6 , then the construction is declared valid, and vice versa. The results of the alpha Cronbach calculation are shown in Table 1 as follows.

\section{Table 1}

The results of Cronbach alpha

\begin{tabular}{lcccc}
\hline Item & Behavioral Intention & Customer Satisfaction & Brand Credibility & Service Quality \\
\hline Cronbach Alpha & 0.825 & 0.748 & 0.825 & 0.964 \\
\hline
\end{tabular}

According to Table 1, Cronbach's alpha value for Behavioral Intention was 0.825 , Brand Credibility 0.825 , customer satisfaction 0.748 , and Service Quality 0.964. The results show that the value of all Cronbach's alpha variables are more than 0.6. 
It can be concluded that all constructs on the variables used in this study are valid. Furthermore, to determine the value of the reliability indicator can be measured using the value of Average Variance Extracted (AVE) and Composite Reliability (CR). The AVE value obtained shows the variance of each variable. Testing criteria for AVE above 0.5. That is, the higher the AVE, the better, and shows a growing diversity of indicators. Meanwhile, the criteria for testing the value of composite reliability are above 0.7 . The higher the $\mathrm{CR}$, the higher the variable reliability value.

Table 2

The summary of composite reliability and average variance extracted

\begin{tabular}{lcc} 
& Composite Reliability & Average Variance Extracted \\
\hline Behavioral Intention & 0.896 & 0.741 \\
Customer Satisfaction & 0.855 & 0.664 \\
Brand Credibility & 0.877 & 0.588 \\
Service Quality & 0.967 & 0.574 \\
\hline
\end{tabular}

Table 2 shows that the value of Composite Reliability in Behavior Intentions is 0.896, Brand Credibility 0.877, Customer Satisfaction 0.855, and Service Quality 0.967. Then, the value of Average Variance Extracted (AVE) in Behavioral Intention is 0.741, Brand Credibility 0.588, Customer Satisfaction 0.664, and Service Quality 0.574. All value of Average Variance Extracted (AVE) are above 0.5 and Composite Reliability values are above 0.7 . It can be concluded that all variables in this study revealed reliable.

\subsection{Inner Evaluation Model (Structural Model)}

Table 3 presents the results inner evaluation.

Table 3

The summary of the inner evaluation

\begin{tabular}{lccc}
\hline Variable & Brand Credibility & Customer Satisfaction & Behavioral Intention \\
\hline R-Square & 0.760 & 0.735 & 0.853 \\
\hline
\end{tabular}

Based on Table 3, it can be concluded that:

1. R-Square Model I is 0.760 , which means the ability construct of Service Quality in explaining the construct Brand Credibility is about 76 percent (high).

2. R-Square Model II is 0.735 , which means the ability construct of Service Quality and Brand Credibility in explaining the constructs Customer Satisfaction is 73.5 percent (high).

3. R-squared Model III is 0.853, which means the ability construct of Service Quality, Brand Credibility, and Customer Satisfaction in explaining the construct Behavioral Intention is 85.3 percent (high).

$f$-Square $\left(f^{2}\right)$

The f-Square test aims to determine how the relative influence of the latent construct is independent of the dependent latent construct.

Table 4

The summary of f-square

\begin{tabular}{lccc}
\hline & Behavioral Intention & Customer Satisfaction & Brand Credibility \\
\hline Behavioral Intention & & & \\
Customer Satisfaction & 0.196 & & \\
Brand Credibility & 0.247 & 0.390 & 2.641 \\
Service Quality & 0.362 & 0.377 & \\
\hline
\end{tabular}

According to Table 4, the relationship between construct Service Quality and Behavioral Intention is 0.362 . It can interpret that there is a strong relationship between those variables. The relationship between construct Brand Credibility and Behavioral Intention is 0.247 . It can interpret that the relationship of variables is quietly strong. The relationship between construct Customer Satisfaction and Behavioral Intention is 0.196. It can interpret that the relationship of variables is quietly strong. The relationship between construct Service Quality and Customer Satisfaction is 0.377 . It can be interpreted that there is strong relationship between them. The relationship between construct Brand Credibility and Customer Satisfaction is 0.390 and it can interpret that there is strong relationship. Then, the relationship between construct Brand Credibility is 2.641 which can interpret that there is very strong relationship. After testing the analysis of internal and external models, the next step is 
to analyze the measurement of the relationship or the relationship between structural constructions (hypothesis testing). According to Ghazali and Latan (2015) in hypothesis testing can be described by t-statistic value and probability value. Testing the hypothesis using a statistical value for alpha $5 \%$ of the t-statistics used was 1.96 . The criterion for acceptance or rejection of the hypothesis is $\mathrm{Ha}$ is accepted and $\mathrm{H} 0$ is rejected, when the t- statistic is more than 1.96 and the probability value is less than 0.05 .

Table 5

The results of path coefficients

\begin{tabular}{|c|c|c|c|c|c|}
\hline & $\frac{\text { Original Sample }}{(\mathrm{O})}$ & $\begin{array}{r}\text { Sample } \\
\text { Mean (M) }\end{array}$ & $\begin{array}{l}\text { Standard } \\
\text { (STDEV) }\end{array}$ & $\begin{array}{r}\text { T Statistics } \\
(|\mathrm{O} / \mathrm{STDEV}|)\end{array}$ & $\begin{array}{c}\mathrm{P} \\
\text { Values }\end{array}$ \\
\hline Service Quality $\rightarrow$ Brand Credibility & 0.872 & 0.873 & 0,026 & 33.839 & 0,000 \\
\hline Service Quality $\rightarrow$ Customer Satisfaction & 0.577 & 0.572 & 0.171 & 3.367 & 0,001 \\
\hline Service Quality $\rightarrow$ Behavioral Intention & 1,170 & 1,184 & 0,064 & 18.388 & 0,000 \\
\hline Brand Credibility $\rightarrow \quad$ Customer Satisfaction & 0.613 & 0.613 & 0.083 & 7.424 & 0,000 \\
\hline Brand Credibility $\rightarrow$ Behavioral Intention & 0.239 & 0.256 & 0.076 & 3,122 & 0,002 \\
\hline Customer Satisfaction $\rightarrow$ Behavioral Intention & 0.429 & 0.436 & 0.114 & 3,774 & 0,000 \\
\hline Service Quality $\rightarrow$ Customer Satisfaction & 0.577 & 0.572 & 0.171 & 3.367 & 0,001 \\
\hline
\end{tabular}

H1: Service Quality has a positive effect on brand Credibility

Based on the calculation of coefficient path, it describes that the value of Original Sample is 0.872, where T-Statistics 33.839 is more than 1.96 and $\mathrm{P}$ value is 0.000 that less than 0.05 . It may conclude that Service Quality has a positive effect on Brand Credibility significantly.

H2: Service Quality has a positive effect on Customer Satisfaction

Based on the calculation of coefficient path, it describes that value of Original Sample is 0.577, where T-Statistics 3.367 is more than 1.96 and $P$ value is 0.001 that less than 0.05. It may conclude that Service Quality has a positive effect on Customer Satisfaction significantly.

H3: Service Quality has a positive effect on Behavioral Intention

Based on the calculation of coefficient path, it describes that value of Original Sample is 1.170, where T-Statistics 18.388 is more than 1.96 and $\mathrm{P}$ value is 0.000 that less than 0.05 . It may conclude that Service Quality has a positive effect on Behavioral Intention significantly.

H4: Brand Credibility has a positive effect on Customer Satisfaction

Based on the calculation of coefficient path, it describes that value of Original Sample is 0.613, where T-Statistics 7.424 is more than 1.96 and $\mathrm{P}$ value is 0.000 that less than 0.05 . It may conclude that Brand Credibility has a positive effect on Customer Satisfaction significantly.

H5: Brand Credibility has a positive effect on Behavioral Intention

Based on the calculation of coefficient path, it describes that the value of Original Sample is 0.239, where T-Statistics 3.122 is more than 1.96 and $\mathrm{P}$ value is 0.002 that less than 0.05 . It may conclude that Brand Credibility has a positive effect on Behavioral Intention significantly.

H6: Customer Satisfaction has a positive effect on Behavioral Intention

Based on the calculation of coefficient path, it describes that value of Original Sample is 0.429, where T-Statistics 3.774 is more than 1.96 and $\mathrm{P}$ value is 0.000 that less than 0.05 . We may conclude that Customer Satisfaction has a positive effect on Behavioral Intention significantly.

Table 6

The results of indirect effects

\begin{tabular}{|c|c|c|c|c|c|}
\hline & $\begin{array}{c}\text { Original Sample } \\
(\mathrm{O})\end{array}$ & $\begin{array}{r}\text { Sample } \\
\text { Mean }(\mathrm{M})\end{array}$ & $\begin{array}{l}\text { Standard } \\
\text { (STDEV) }\end{array}$ & $\begin{array}{r}\text { T Statistics } \\
(|\mathrm{O} / \mathrm{STDEV}|)\end{array}$ & $\begin{array}{c}\mathrm{P} \\
\text { Values }\end{array}$ \\
\hline Service Quality $\rightarrow$ Brand Credibility $\rightarrow$ Behavioral Intention & 0.208 & 0.223 & 0.068 & 3,071 & 0,002 \\
\hline $\begin{array}{l}\text { Brand Credibility } \rightarrow \text { Customer Satisfaction } \rightarrow \text { Behavioral In- } \\
\text { tention }\end{array}$ & 0.206 & 0.223 & 0.063 & 2,940 & 0,002 \\
\hline Service Quality $\rightarrow$ Customer Satisfaction $\rightarrow$ Behavioral Intention & 0,242 & 0,242 & 0,047 & 3,039 & 0,002 \\
\hline Service Quality $\rightarrow$ Brand Credibility $\rightarrow$ Customer Satisfaction & 0.374 & 0.383 & 0.059 & 5.365 & 0,001 \\
\hline $\begin{array}{l}\text { Service Quality } \rightarrow \text { Brand Credibility } \rightarrow \text { Customer Satisfaction } \rightarrow \\
\text { Behavioral Intention }\end{array}$ & 0,375 & 0.385 & 0.051 & 5.436 & 0,001 \\
\hline
\end{tabular}


According to Table 6, assessing the effect of Service Quality variables on Behavior Intention with Brand Credibility as a mediating variable is to consider to the Original Sample value of 0.208, T-Statistics of 3.071 which is more than 1.96, and P of 0.002 which is less than 0.05. Thus, it can be concluded that Service Quality has a positive effect on Behavioral Intention significantly, with Brand Credibility as a mediating variable. We have determined the effect of Brand Credibility on Behavioral Intention with Customer Satisfaction as a mediating variable which is equal to 0.206 with T-Statistics of 2.940 which is more than 1.96 and $\mathrm{P}$ value of 0.002 which is less than 0.05 . Thus, it can be concluded that Brand Credibility has a positive effect on Behavioral Intention significantly, with Customer Satisfaction as a mediating variable. The effect of Quality Service on Behavioral Intention with Customer Satisfaction as a mediating variable is to consider to the Original Sample value of 0.242 , with T-Statistics of 3.039 which is more than 1.96 and $\mathrm{P}$ of 0.002 which less than 0.05 . Thus, it can be concluded that the Quality Service has a positive effect on Behavioral Intention significantly, with Customer Satisfaction as a mediating variable. Furthermore, to determine the effect of Quality Service on Customer Satisfaction with Brand Credibility as a mediating variable we need to consider the Original Sample values of 0.374 with T-Statistics of 5.365 which is more than 1.96 and $\mathrm{P}$ of 0.001 which is less than 0.05 . Thus, it can be concluded that Quality Service has a positive effect on Customer Satisfaction with Brand Credibility as a mediating variable.

\section{Conclusion}

According to data processing, data description, and data analysis, it can be concluded that:

1. Service Quality has a positive and significant influence on Brand Credibility, which means that a better level of Service Quality will increase Brand Credibility.

2. Service Quality has a positive and significant influence on Behavioral Intention directly and also indirectly mediated by Customer Satisfaction, which means a better level of Service Quality will increase Customer Satisfaction and also Behavioral Intention.

3. Brand Credibility has a positive and significant influence on Behavioral Intention directly and also indirectly mediated by Customer Satisfaction, which means a better level of Brand Credibility will increase Customer Satisfaction and also Behavioral Intention.

4. Service Quality has a positive and significant influence on Behavioral Intention, which means a better level of Service Quality will increase Behavioral Intention.

5. Brand Credibility has a positive and significant influence on Behavioral Intention, which means a better level of Brand Credibility will increase Behavioral Intention.

6. Customer Satisfaction has a positive and significant influence on Behavioral Intention, which means a better level of Customer Satisfaction will impact the increasing of behavioral intention.

\section{Suggestion}

1. Lion Air should consider the appropriateness of prices and quality of services provided to airline passengers.

2. Lion Air should always improve the quality of service by conducting regular training for its personnel, and for increasing the credibility and passenger satisfaction.

3. Lion Air should always consider the company's credibility by trying to fulfill promises in accordance with company commitments to minimize the number of passenger complaints.

4. The company must provide a memorable experience that Lion Air is the best flight partner, so passengers choose to enjoy their next flight with Lion Air.

5. The company must provide excellent service quality, thus encouraging passengers to gladly recommend Lion Air to their friends and relatives.

\section{References}

Alotaibi, MM, \& John Mason, K. (2010). Evaluation of “AIRQUAL” Measuring Scale for Airline Service Quality and Its Effect on Customer Satisfaction and Loyalty. Cranfield University.

Armstrong, G., Kotler, P., Harker, M., \& Brennan, R. (2018). Marketing an Introduction, 4th ed., Pearson.

Chiu, S., Liu, C., \& Tu, J. (2016). The influence of tourists' expectations on purchase intention: Linking marketing strategy for low-cost airlines. Journal of Air Transport Management, 53, 226-234.

Cronin, J., J., \& Taylor, S., A. (1992). Measuring service quality: a re-examination and extension. Journal of Marketing, 56 (3), 55-68. 
Ekiz, E.H., Hussain, K., \& Bavik, A. (2015). Perceptions of service quality in north Cyprus national airline. Creating Customer Value in Tourism and Hospitality Industry, April, 778-790.

Erdem, T., \& Louviere, J. (2002). The impact of brand credibility on the consumer price sensitivities across multiple product categories. International Journal of Research in Marketing, 19 (1), 1-19.

Erdem, T., \& Swait, J. (2004). Brand credibility, brand consideration, and choice. Journal of Consumer Research, 31(1), 191198.

Erdem, T., Swait, J., \& Valenzuela, A. (2006). Brands as signals: A cross-country validation study. Journal of Marketing, 70 (1), 34-49.

Fadhilah, U.N., \& Puspita, R. (2018, November). YLKI: Lion Most Complained Seven Years. Republika.

Farooq, M.S., Regards, M., Fayolle, A., Jaafar, N., \& Ayupp, K. (2018). Impact of service quality on customer satisfaction of airlines in Malaysia: A PLS-SEM approach. Journal of Air Transport Management, 67 (December 2017), 169-180.

Hodge, A., \& Rayda, N. (2018, November). Jakarta 'Soft' on Lion Air despite Customer Complaints. The Weekend Australian.

International Airport Review. (2019). The Top 20 busiest Airports in the World by Passenger Number. In International Airport Review.

Jeng, S.P. (2016). The influences of airline brand credibility on consumer purchase intentions. Journal of Air Transport Management, 55, 1-8.

Jiang, W.H., Li, Y.Q., Liu, C.H., \& Chang, Y.P. (2017). Validating a multidimensional perspective of brand equity on motivation, expectation, and behavioral intention: A practical examination of culinary tourism. Asia Pacific Journal of Tourism Research, 22(5), 524-539.

Karatepe, O.M., \& Avci, T. (2002). Measuring service quality in the hotel industry: Evidences from northern Cyprus. Anatolia, $13(1), 19-32$.

Kim, YK, \& Lee, HR (2011). Customer satisfaction using low cost carriers. Tourism Management, 32(2), $235-243$.

Koklic Kos, M., Kukar-Kinney, M., \& Vegelj, S. (2017). An investigation of customer satisfaction with low-cost and fullservice airline companies. Journal of Business Research, 80 (May), 188-196.

Leong, L. Y., Hew, T. S., Lee, V. H., \& Ooi, K. B. (2015). An SEM-artificial-neural-network analysis of the relationships between SERVPERF, customer satisfaction and loyalty among low-cost and full-service airline. Expert Systems with Applications, 42(19), 6620-6634.

Nadiri, H., Hussain, K., Ekiz, EH, \& Erdogan, S. (2008). An investigation on the Factors Influencing Passengers' loyalty in the North Cyprus National Airline. The TQM Journal, 20(3), 265-280.

Parasuraman, A., Zeithaml, V. A., \& Berry, L. L. (1988). Servqual: A multiple-item scale for measuring consumer perc. Journal of Retailing, 64(1), 12.

Rajaguru, R. (2016). Role of value for money and service quality on behavioral intention: A study of full service and low cost airlines. Journal of Air Transport Management, 53, 114-122.

Rush, A. (2015, January). Lion Air Receives Highest Number of Complaints. Tempo.

Saha, G.C., \& Theingi, T. (2015). Service quality, satisfaction, and behavioral intentions A study of the low-cost airline carriers in Thailand. (May 2009).

Shafranskaya, I., \& Potapov, D. (2014). An empirical study of consumer-based city brand equity from signaling theory perspective. Place Branding and Public Diplomacy, 10(2), 117-131.

Spry, A., Pappu, R., \& Cornwell, TB (2011). Celebrity endorsements, brand credibility and brand equity. European Journal of Marketing, 45(6), 882-909.

Topbrand. (2019). Top Brand Award 2019. worldairlineawards. (2020). The World's Best Airlines of 2019.

Zeithaml, V.A., Berry, L.L., \& Parasuraman, A. (1996). The behavioral consequences of service quality. Journal of Marketing, 60(2), 31-46.

\section{Table A1}

Operationalization Variables

\begin{tabular}{lll}
\hline Variable (Construct) & Items & References \\
\hline Service Quality & 1. Airline Tangibles \\
a) The interior of airline looks modern & (Nadiri et al., 2008) \\
b) The cleanliness of the toilet maintained \\
c) Cleanliness of seating area \\
d) Comfortable seat \\
e) The good quality of air condition during flight \\
f) Cabin crew uniforms are visually attractive \\
2. Terminal Tangibles \\
a) Airlines terminal is large enough to serve passengers \\
b) Trolley availability is sufficient \\
c) Security control system is available at the airport \\
d) Effective sign system regarding flight information \\
e) Check-in / baggage counter is sufficient \\
f) Airport terminal waiting room is convenient \\
g) Cleanliness of toilet is maintained
\end{tabular}



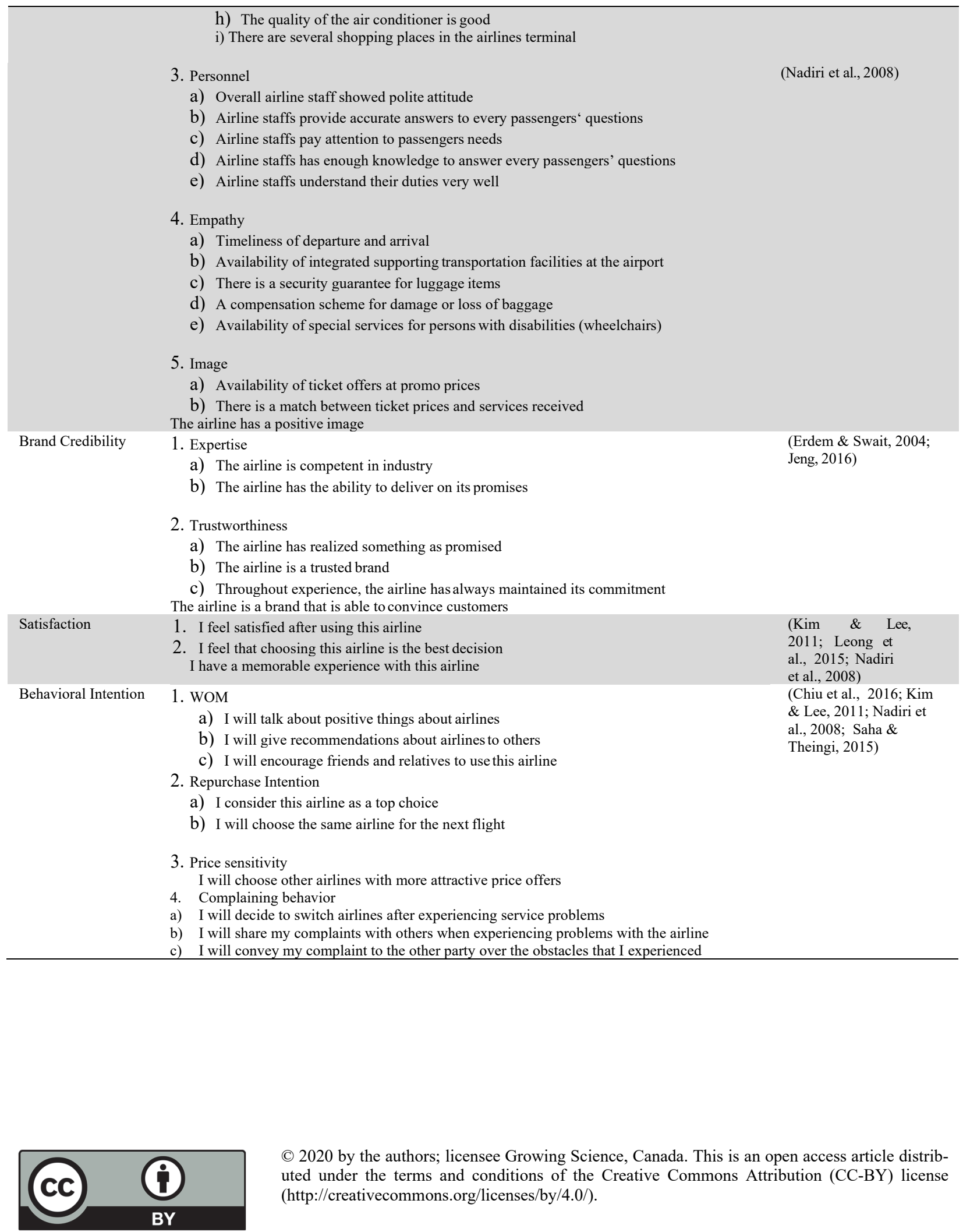

(C) 2020 by the authors; licensee Growing Science, Canada. This is an open access article distributed under the terms and conditions of the Creative Commons Attribution (CC-BY) license (http://creativecommons.org/licenses/by/4.0/). 